\title{
Controversy of Criminal Sanctions Against Narcotics Abuser in Act No. 35 of 2009
}

\author{
Bambang Rudi Hartoko ${ }^{1}$ and Umar Ma'ruf ${ }^{2}$
}

Abstract. Abuse of narcotics in Indonesia tends to increase. Its effects, not only harm themselves but also the perpetrators of the surrounding environment. On the one hand, drug abusers are the ones who need to be helped to all treatment, but on the other hand, the public and law enforcement thought early abusers are criminals who should be punished. As a legal basis in the eradication of narcotics, Act No. 35 of 2009, there are still concerns about the notion of juridical criminal narcotics, which are related to the sanctions that can be imposed by the judge, especially for sanctions in the form of rehabilitation measures.

Keywords: Criminal Sanctions; Abusers; Narcotics.

\section{Introduction}

The development of narcotic crime as transnational crime and organized crime has made Indonesia as a country that backs possess drugs emergency status. Narcotics initially only used as a tool for religious rituals, and in addition, it is also used for treatment. The first type of drug-use in the beginning is usually referred to as the opium or opium or opium. ${ }^{3}$

Narcotics abuser had reached in the emergency level, not just the quantity of the abuse were more numerous and widespread, but users also have spread almost all walks of life ranging from students to state officials are also involved in narcotic crime. Companies have a tendency narcotics increase, and that is unfortunate drug users are now beginning to do the government and law enforcement officials.

Drug abuse by some circles in general because they have the presumption that such substances promising something that can give a sense of pleasure, comfort, pleasure, tranquility, and eliminate the problem. The existence of these assumptions, victims of drug became interested and caught up in the abuse of narcotics, even though it is only perceived false.

At present, the development of drug use is increasing rapidly and not for medical purposes or the purpose of the development of science, but in order to gain a very big advantage, namely by trading in illegal narcotics or illicit trafficking to various countries.

At this time, the government is aggressively combating drug abuse. Abuse of drugs already are transnational (transnational criminality) it may cross national borders (borderless countries) were performed by using the modus operandi and advanced

\footnotetext{
${ }^{1}$ Student of Master of Law, Universitas Islam Sultan Agung Semarang and State Attorney of Semarang City E-mail: rudikennymahesa@gmail.com

${ }^{2}$ Faculty of Law, UNISSULA Semarang

${ }^{3}$ Kusno Adi, 2009,Diversi Sebagai Upaya Alternatif Penanggulangan Tindak Pidana Narkotika Oleh Anak, First Edition, UMM Press, Malang, p 3.
} 
technology, with network management neat and supported by the organization's network wide, then enter to Indonesia as a transit country (transit state) or even as a country of trafficking in narcotics illegally (point of market state), and had a lot of casualties, especially among the young generation, to the degree that so very harmful aspects of community life, nation and state.

Laws governing narcotics and illegal drugs, namely Act No. 5 of 1997 on Psychotropic Substances and the Act No. 22 Of 1997 on Narcotics which has been converted into Act No. 35 of 2009 by means of penal (criminal law) ${ }^{4}$. to combate narcotics. The danger of abuse of this provision shall be punishable by criminal penalties of height and weight. In addition to a sentence of imprisonment, the perpetrator was also sentenced to a criminal fine.

Criminal threats in Act No. 35 Of 2009 air-levels in accordance with the act and the total weight of each type. In addition, the provisions of Article 113 paragraph (2), Article 114 paragraph (2), Article 115 paragraph (2), Article 116 paragraph (2), Article 118 paragraph (2), Article 119 paragraph (2), Article 121 paragraph (2) and Article 38 (2) of Act No. 35 of 2009tercantum the imposition of the death penalty in addition to imprisonment and criminal fines. The problem is how the mechanism defined, and whether to impose the death penalty must be accompanied by a fine of normative juridical considering it can not be justified. ${ }^{5}$

In the imposition of criminal sanctions, the doers have a role, position, and different saction, both on a per-rule of law that govern it, and based on the role and impact of deeds.

Classification of the doers that must be observed by the law enforcement agencies in the implementation of Act No. 35 of 2009. The provisions of criminal to narcotic abuser crime in Act No. 35 of 2009 ruled in Article 111 to Article 147.

Associated with criminals, one of the things that is the problem in Act No. 35 of 2009 was about uncertainty meaning and status among addicts, abusers, and narcotics victims. Because of uncertainty in the meaning status, then other arrangements being biased and unconcistency. Of course, in practice, this leads directly narcotics impact. Lawyer order them in terms of providing medical and social rehabilitation for abusers and drug addicts.

From the above discussion, the authors formulate the problem of: How Controversy Of Criminal Sanctions Against Narcotics Abuser In Act No. 35 of 2009?

\section{Discussion}

The term narcotic is known in Indonesia in terms of grammar comes from the English language meaning "drugs", which is synonymous with the word narcosis in Greek

\footnotetext{
${ }^{4}$ Barda Nawawi Arief, 2013,Kapita Selekta Hukum Pidana, Cetakan Ketiga, Citra Aditya Bakti, Bandung, p. 94.

${ }^{5}$ Andi Hamzah dan Boedi Dwiyani Sri Marsita Goenanti, 2011, Kejahatan Narkotika \& Psikotropika, First Edition, Universitas Trisakti, Jakarta, p. 33-34.
} 
means "euthanize" or "anesthetize". In general, the drug means a substance that can cause changes in feeling, the atmosphere observation / vision due to these substances affect the central nervous system. ${ }^{6}$

Definition of narcotics, according to Article 1 paragraph 1 of Act No. 35 Of 2009 on Narcotics is:

Substances or drugs derived from plant or not plant, either synthetic or semisynthetic, which can cause a reduction or alteration of consciousness, loss of taste, reduced until it disappears the pain, and can lead to dependence, which differentiated into factions as attached this Act.

While the understanding of drug abuse as early on Article 1 paragraph 15 of Act No. 35 of 2009 is: "People who use narcotics without authority or unlawfully ". Abuse of narcotics is a type of crime that has a (potential) social impact very broad and complex, more so children. The social impact of drug abuse which children do not only caused by the impact will bear the suffering and destruction both physically and mentally extremely long, but also because of the complexity in tackling especially when the choice fell on the use of criminal law as a means. ${ }^{7}$

Dadang Hawari stated that the threats and dangers of narcotics usage continuously and unsupervised and if not immediately teraphy and preventive effects both physical and psychological dependence is very strong against the wearer. ${ }^{8}$

As mentioned that one of the things that a point in Act No. 35 of 2009 is the uncertainty on the definition and status among addicts, abusers, and victims of drug abuse. The lack of clarity in the definition and the status, results in other settings to be biased and confusing. Of course, in practice, this case directly impact the lawyer-order drugs, one of which is in terms of providing medical and social rehabilitation for abusers and drug addicts.

In Act No. 35 of 2009, there were four (4) understanding of drug users are addicts, abusers, victims of abuse, and patient narcotics. ${ }^{9}$

- Narcotic mean an addict man who use narcotics and in a state of dependence, reproduce physically and psychologically;

- Abusers are people who use narcotics without rights or against the law;

- Victims of abuse of narcotic means someone who does not intentionally use narcotics because lured, tricked, deceived, coerced, and / or threatened use of narcotics;

- Patients of narcotics not found understanding, but the reference to Article 53 of Act No. 35 of 2009, means the patient is a person who was given the right to possess,

\footnotetext{
${ }^{6}$ Kusno Adi, 2009,Kebijakan Kriminal Dalam Penanggulangan Tindak Pidana Narkotika Oleh Anak, First Edition, UMM Press, Malang, p. 12.

${ }^{7}$ Ibid., p. 17.

${ }^{8}$ Ibid., p. 18 -19.

${ }^{9}$ Dahlan, 2017, Problematika Keadilan Dalam Penerapan Pidana Terhadap Penyalahguna Narkotika, Edisi Pertama, Cetakan Kesatu, Deepublish, Yogyakarta, p. 72.
} 
store, and / or carrying narcotics in the number and kind of limited in accordance with the per-disapproval doctor sake treatment.

The understanding differences also result in differences in the imposition of criminal sanctions, and would be more complicated if it is associated with the imposition of sanctions in the form of medical rehabilitation. Of course, criminal punishment is intended to provide a deterrent effect and improvement of the perpetrator.

An examination of the offender improvement, measures of effectiveness lies in the aspects of specific prevention of the criminal. So, its size lies in the criminal matter how far away (in prison) have an influence on the offender or convicted. There are two aspects of criminal influence against the convict, the early prevention aspects (deferent aspect) and aspects of improvement (reformative aspect). ${ }^{10}$

Article 4 of Act No. 35 of 2009 states that one purpose of the establishment of the Act is to shortly assure attempts medical and social rehabilitation for abusers and drug addicts, whereas in Article 54 of Act No. 35 of 2009 states that drug addicts and victims of drug abuse are required to undergo medical rehabilitation and social rehabilitation. If use construction of Article 54 of Act No. 35 of 2009, the narcotics abuser do not qualify as someone who can be given the medical and social rehabilitation measures as provided for in Article 4 of Act No. 35 of 2009.

The problems for other legitimate contained in Article 103 of Act No. 35 of 2009, which states that the treatment and / or treatment may be terminated or assigned by the judge for drug addicts guilty or not guilty of narcotics. In Article 103 of Act No. 35 of 2009, the term used is a drug addict.

Another problem is in Article 127 of Act No. 35 of 2009, which uses the term abusers and victims of abuse of narcotics. Article 127ayat (2) states that a judge shall take into account in deciding the provisions of Article 54, Article 55 and Article 103 of Act No. 35 of 2009. In the articles, the term abusers can not be found.

As mentioned that the main purpose of the enactment of Act No. 35 of 2009 with reference to Article 4 of Act No. 35 of 2009 was a medical rehabilitation. Medical rehabilitation arrangements set out in Chapter IX of Part Two on Rehabilitation (Treatment). Starting from Article 54 to Article 59 of Act No. 35 of 2009yang arrange rehabilitation for drug users, but it is also scattered in various other articles.

Article 54 of Act No. 35 of 2009menyatakan that for drug addicts and victims of substance abuse, rehabilitation is mandatory. Supposedly mandatory nature of rehabilitation has become a major benchmark for law enforcement officials to take action against narcotics users. Article 54 of Act No. 35 of 2009 closely connected to Article 127 of Act No. 35 of 2009.

In Article 127 paragraph (2) of Act No. 35 of 2009 stated that the judge shall take into account the provisions of Article 54, Article 55 and Article 103 in decisions. However, even though they are mandatory, in practice depends on the investigator and

\footnotetext{
${ }^{10}$ Dawud Budi Sutrisno, 2012,Pengaturan \& Penerapan Hukum Pidana Narkoba, First Edition, Yuma Pustaka, Surakarta, p. 54.
} 
prosecutor. If the public prosecutor does not invoke the provisions of Article 127 of Act No. 35 of 2009 in charge or charges, then the placement of drug users in rehabilitation institutions difficult. Including the most fatal condition, which the judges decide to use Article 127 of Act No. 35 of 2009, but did not consider the provisions of rehabilitation. ${ }^{11}$

So is the tendency of the public prosecutor and judge who more looking at drug users as criminal actor. Basiccaly may be a trespasser, in that abusing action, he does not carry, buy, store and has a narcotic, especially if caught and found evidence. With that understanding then the automatic application of article on rehabilitation difficult to implement. ${ }^{12}$

Whereas Act No. 35 of 2009 provides a space large enough for the judge to give a verdict rehabilitation. Article 103 states that:

- Judges who hear cases drug addicts can:

- Disconnecting to order the following treatment and / or treatment through the drug rehabilitation if abuser convicted criminal do narcotics abuse; or

- Assign to live concered ordered the treatment and / or treatment through rehabilitationif addict is not proven commiting narcotic crime.

- The period of treatment and / or care for addicts referred to in paragraph (1) subaccount the addicts as serving time period.

However, Article 103 of Act No. 35 of 2009menggunakan word "may" in aplicate the authority of the judge. It means that its pitch-called facultative (optional), and not something that is required to do. At this point, the placement in the rehabilitation of drug users have also become very dependent on the views of judges. In addition to Act No. 35 of 2009, there is also a Government Regulation No. 25 of 2011, which in Article 13 paragraph (3) mentions drug addicts who are undergoing a judicial process can be placed in a medical rehabilitation institution and / or social rehabilitation. Furthermore, in paragraph (4) that the placement in a medical rehabilitation institution and / or social rehabilitation for drug addicts who are undergoing the process of justice is the authority of the investigator, prosecutor, ${ }^{13}$

The number of drug abusers tend to increase. The public and law enforcement officers themselves, drug abusers are considered criminals who should be punished. This situation gives rise to other problems such as load correctional be over capacity, the penitentiary became a safe haven for narcotic abuse and the emergence of other crimes, in addition to drug trafficking are also rife in prisons even several times found drug production within the institution correctional. ${ }^{14}$

Basically sanctioned in Act No. 35 of 2009 embraced a double track system, namely in the form of criminal sanctions and the sanctions measures. Rehabilitation is one form of sanctions measures. In Article 103 affirmed the judge can decide or define drug

\footnotetext{
${ }^{11}$ Dahlan, op.cit., p. 76.

${ }^{12}$ Ibid.

${ }^{13}$ Ibid., p. 77.

${ }^{14}$ Ibid., p. 77-78.
} 
addicts to undergo treatment or care. The period of treatment and / or care of a sentence is calculated as period. This is consistent with the one goal of the establishment of Act No. 35 of 2009, which guarantees the setting efforts of medical and social rehabilitation for drug addicts. However, judges tend to impose a sanction of imprisonment in addicts. As a result, drug addicts languishing in prison without being given the opportunity rehabilitated, so that rehabilitation has not run optimally. ${ }^{15}$

The imposition of criminal sanctions in the form of imprisonment for abusers, addicts, drug abusers or victims will not solve the drug problem. Transferring abusers, addicts, abusers or victims narcotic in prison without any attempt to cure, will plunge into illicit trafficking. Basically addiction drug addicts have properties with a high relapse rate, so it can not recover by itself, so they need to be helped to cure her.

Donald Clemmer, a sociologist argued that their prisonization in prison. Prisonization explains that a person who entered the prison will be faced with various problems that live and thrive in prison. This prisonization inmates not previously made evil become (more) evil. Thus, it is not excessive if there is a presumption that the prisons are universities for evil. ${ }^{16}$

Use and narcotic abuse actions constitute a crime, so that the perpetrators as appropriate conducted legal proceedings and criminal sanctions. However, for the moment law enforcement against abusers and addicts do not always use the penal, because of the necessity of rehabilitation for addicts who report themselves at a particular agency recipients to report, as in Article 54 of Act No. 35 of 2009.

Shifting the criminalization of acts of corporal punishment be commuted to a depenalization process for development or per-shear legal values in society affecting the development of the legal value of the norms of criminal law. The act remains a despicable act, but does not deserve a heavy subject to criminal sanctions, more precise light subject to criminal sanctions or measures. The reason for determining depenalization against and victims of drug addicts, because they are sick so that required treatment with therapy and medication in order to recover. For the victims of drug abuse, in fact they are not aware of that has been done is because they committed the act because blandishments others that need to be saved to be rehabilitated, ${ }^{17}$

For the implementation of the provisions of Article 103 letters $a$ and $b$ of Act No. 35 of 2009 issued SEMA No. 04 of 2010. SEMA is only focused on two conditions, namely if found guilty and not guilty of the crime of narcotics, which means after the examination process in the trials had been completed. Not found arrangements regarding the placement of drug addicts in rehabilitation institutions ranging from the stage of investigation, prosecution, until the process of examination in court. Then the

\footnotetext{
${ }^{15}$ Ibid.

${ }^{16}$ WP Ratna, 2017, Aspek Pidana Penyalahgunaan Narkotika, Rehabilitasi Versus Penjara (Menyoroti Pasal 127 UU No. 35 Tahun 2009), First Edition, Legality, Yogyakarta, p. 110.

${ }^{17}$ Dahlan, op.cit., p. 81.
} 
Supreme Court publishes SEMA No. 03 of 2011. One of the reasons SEMA issuing of these is the problem of addicts, victims of drug abuse is increasing. While on the other hand, the efforts of treatment and / or care through the rehabilitation process has not been optimal. ${ }^{18}$

SEMA No. 03 of 2011 also provides guidance in implementing Article 103 of Act No. 35 of 2009 and Article 13 paragraph (2) of Government Regulation No. 25 of 2011, in which the command runs medical and social rehabilitation can only be done under a court decision for addicts found guilty of narcotic crime, a court warrant for drug addicts who are not guilty, and a court warrant for a suspect who is still in the process of investigation or prosecution.

Here, the judge has a central position to determine whether a person can be placed in the medical and social rehabilitation institutions during the process of investigation, prosecution, until the process of the trial, which the judge's assessment contained in the form of confirmation.

\section{Closing}

\subsection{Conclusion}

Juridical Problems in Act No. 35 Tahun2009, contained in Article 4, Article 54, Article 103, and Article 127 Act No. 35 of 2009, which is associated with the sanctions measures in the form of rehabilitation for drug abusers. For the abuse-of-use would be more appropriately carried out rehabilitation rather than imprisonment, because they are more in need of rehabilitation to recovery. SEMA No. 03 of 2011 as provisions for the implementation of Act No. 35 of 2009 which emphasizes the application of sanctions in the form of rehabilitation measures, while providing a central position for the judge to establish rehabilitation for offenders.

\subsection{Suggestion}

There must be a new paradigm in the treatment of addicts, abusers and victims of drug abusers. Law enforcement officials must prioritize rehabilitation action in the form of sanctions in order to save their future, and support other law enforcement officers to the judges in deciding or establish rehabilitation is needed.

\section{Bibliography}

[1] Andi Hamzah dan Boedi Dwiyani Sri Marsita Goenanti, 2011, Kejahatan Narkotika \& Psikotropika, First Edition, Universitas Trisakti, Jakarta.

[2] Barda Nawawi Arief, 2013, Kapita Selekta Hukum Pidana, Cetakan Ketiga, Citra Aditya Bakti, Bandung.

\footnotetext{
${ }^{18}$ Ibid., p. 86.
} 
[3] Dahlan, 2017, Problematika Keadilan Dalam Penerapan Pidana Terhadap Penyalahguna Narkotika, Edisi Pertama, Cetakan Kesatu, Deepublish, Yogyakarta.

[4] Dawud Budi Sutrisno, 2012, Pengaturan \& Penerapan Hukum Pidana Narkoba, First Edition, Yuma Pustaka, Surakarta.

[5] Kusno Adi, 2009, Diversi Sebagai Upaya Alternatif Penanggulangan Tindak Pidana Narkotika Oleh Anak, First Edition, UMM Press, Malang.

[6] ..............., 2009, Kebijakan Kriminal Dalam Penanggulangan Tindak Pidana Narkotika Oleh Anak, First Edition, UMM Press, Malang.

[7] WP Ratna, 2017, Aspek Pidana Penyalahgunaan Narkotika, Rehabilitasi Versus Penjara (Menyoroti Pasal 127 UU No. 35 Tahun 2009), First Edition, Legality, Yogyakarta. 